\title{
Studi Pemikiran Dakwah KH. X tentang Gerakan Dakwah Tarbiyah
}

\section{Fitria Nur Hasannah*, Wildan Yahya}

\author{
Prodi Komunikasi Penyiaran Islam, Fakultas Dakwah, Universitas
} Islam Bandung, Indonesia.

*fitrianurhasannah28@gmail.com, yahyawildan@gmail.com

\begin{abstract}
KH. X is a da'wah figure who is very well known by the Tarbiyah movement. The alignment of his personal da'wah with the Tarbiyah movement influenced the development of Tarbiyah da'wah in Indonesia. The preaching thought of KH. X was a good change for the Tarbiyah movement. This research is a research on the study of the da'wah thought of KH. X about the Tarbiyah da'wah movement. The purpose of this study was to determine the thought of da'wah by looking at the material, methods and media of da'wah KH. X and the Tarbiyah Da'wah Movement KH. Rahmat Abdullah. This research uses descriptive qualitative method. The type of research is library research with content analysis techniques on research data sources. The results of this study include four discussions. First, the material for preaching KH. X which is divided into three problems, namely the problem of aqidah, shari'ah and morals contained in the books "For you Da'wah Cadres" and "The Inheritance of the Murabbi, the Pillars of Fundamentals". Second, the method of preaching KH. X is divided into three methods, namely bil qalam (writing), bil lisan (voice) and bil haal (morals/deeds). Third, the propaganda media KH. X is in line with the methods used, namely books, lectures, radio and example. Fourth, the Tarbiyah missionary movement KH. Rahmat Abdullah. His da'wah thoughts and their role and influence for the Tarbiyah da'wah movement made KH. X is known as the Sheikh of Tarbiyah Indonesia.
\end{abstract}

Keywords: KH. X, Da'wah Thought, Tarbiyah Movement.

Abstrak. KH. X merupakan tokoh dakwah yang sangat di kenal oleh gerakan Tarbiyah. Keselarasan dakwah pribadinya dengan gerakan Tarbiyah, mempengaruhi perkembangan dakwah Tarbiyah di Indonesia. Pemikiran dakwah KH. X menjadi perubahan yang baik bagi gerakan Tarbiyah. Penelitian ini merupakan penelitian mengenai studi pemikiran dakwah KH. X tentang gerakan dakwah Tarbiyah. Tujuan penelitian ini untuk mengetahui pemikiran dakwah dengan melihat materi, metode dan media dakwah KH. X serta Gerakan dakwah Tarbiyah KH. Rahmat Abdullah. Penelitian ini menggunakan metode kualitatif deskriptif. Jenis penelitiannya studi pustaka (library research) dengan teknik analisis isi (content analysis) terhadap sumber-sumber data penelitian. Hasil penelitian ini mencakup empat pembahasan. Pertama, materi dakwah KH. X yang terbagi di dalam tiga masalah, yaitu masalah aqidah, syari'ah dan akhlak yang terdapat pada buku "Untukmu Kader Dakwah" dan "Warisan Sang Murabbi, Pilar-pilar Asasi". Kedua, metode dakwah KH. X terbagi ke dalam tiga metode, yaitu bil qalam (tulisan), bil lisan (suara) dan bil haal (akhlak/ perbuatan). Ketiga, media dakwah KH. X selaras dengan metode yang digunakan, yaitu buku, ceramah, radio dan keteladanan. Keempat, gerakan dakwah Tarbiyah KH. Rahmat Abdullah. Pemikiran-pemikiran dakwahnya serta peran dan pengaruhnya bagi pergerakan dakwah Tarbiyah membuat KH. X digelari Syaikh Tarbiyah Indonesia.

Kata Kunci: KH. X, Pemikiran Dakwah, Gerakan Tarbiyah. 


\section{A. Pendahuluan}

Islam adalah agama rahmatan lil 'alamin yang turun ke dunia ini untuk menumpas berbagai kemusyrikan yang ada di seluruh dunia. Islam datang dengan dua hal sebagai dasar utama, yaitu Al-Qur'an dan Sunnah. Maka dengan menggunakan dua hal dasar utama tersebut, Islam selalu memerintahkan pemeluknya untuk senantiasa melaksanakan dakwah di dalam kehidupan. Maju mundurnya umat Islam sangat berpengaruh dengan kegiatan dakwah yang dilaksanakannya.

Menurut Syekh Muhammad Khidr Husain dalam bukunya Al-Dakwah ila al Ishlah dakwah adalah upaya untuk memotivasi orang agar berbuat baik dan mengikuti jalan petunjuk, dan melakukan amar ma'ruf nahi munkar dengan tujuan mendapatkan kesuksesan dan kebahagiaan di dunia dan di akhirat. Dalam kegiatan berdakwah tentu ada da'i yang menyampaikan dakwah dan mad'u adalah sasaran dakwahnya. Dalam berdakwah, seorang da'i menyampaikan dakwah Islam tentu dengan adanya pemikiran-pemikiran dakwahnya.

Pemikiran adalah sebuah istilah yang bergantung pada pandangan seseorang berkenaan dengan metafisika, universalitas dan epistemologi dengan menggunakan suatu dialog batin yang menggunakan ide-ide abstrak yang sama sekali tidak fiktif, yang memiliki realitas sendiri untuk melahirkan ide-ide umum, yang mungkin saja bercorak epifenomenalisme (penampakan sisi luar). Maka pemikiran dakwah merupakan suatu pandangan atau hasil pandangan yang dituangkan untuk berdakwah atau dakwah merupakan tujuan atas pemikirannya, yang di mana untuk mengajak manusia kepada jalan yang benar (kepada Allah Swt).

Dalam menuangkan pemikirannya tentu seorang tokoh dakwah tak hanya melakukan penuangan pandangannya hanya karena ideologi saja, tetapi dengan melakukan riset literatur. Sejalan dengan perintah Allah Swt untuk banyak membaca maka selayaknya untuk kaum intelektual Islam terutama seorang da'i dapat menyalurkan pengetahuannya dan pemikirannya tentang ajaran Islam dalam sebuah tulisan.

Begitu juga dakwah yang dilakukan oleh KH. Rahmat Abdullah. Beliau merupakan tokoh dakwah yang banyak menuangkan pemikiran-pemikirannya dengan sebuah tulisan. Tulisan-tulisan beliau berisi materi-materi dakwah dalam permasalahan aqidah, syari'ah, dan akhlak dengan mengaitkan nasihat-nasihat dan kisah-kisah terdahulu. Tidak hanya menggunakan metode bil qalam beliau menyampaikan materi dakwah, ada beberapa metode yang biasa beliau gunakan, yaitu bil lisan dan bil haal.

Media dakwah KH. X selaras dengan metode dakwahnya yaitu, media tulisan seperti membuat buku dan mengisi rubrik di majalah-majalah Islam. Media lisan dan elektronik seperti mengisi ceramah, kajian, pengajian, mengajar dan menjadi pembicara di rubrik radio. Serta media keteladanan, dengan akhlak atau perbuatan yang beliau lakukan.

Dalam perjalanan dakwahnya, KH. X memiliki ketertarikan pada sebuah gerakan dakwah. Gerakan dakwah bagi beliau adalah wadah untuk menyempurnakan dakwahnya. Gerakan dakwah atau da'wah harakah bermakna dakwah dengan atau melalui sistem pergerakan. Sesuai dengan namanya, aliran dakwah yang satu ini lebih menekankan aspek tindakan (aksi) ketimbang wacana (teoritisasi).

Gerakan dakwah yang dimasuki oleh KH. X adalah gerakan Tarbiyah. Gerakan Tarbiyah memiliki perbedaan dengan gerakan dakwah lainnya, yang terletak pada pola pendekatan, titik kelimuan yang disusun secara integral dan disajikan dengan tujuan menjadi lebih aplikatif. Dalam gerakan dakwah Tarbiyah, guna meneruskan perjuangan dakwah, maka adanya pembinaan kader. Karena pembinaan kader menjadi salah satu agenda dakwah pada era saat ini. Sehingga dapat mencetak kader-kader dakwah yang bisa melanjutkan estafet dakwah.

Peran dan pengaruh dakwah KH. X dalam gerakan Tarbiyah cukup banyak. Dengan keterlibatan pemikiran-pemikiran dakwah beliau dari berbagai segi ilmu, perbuatan atau akhlak yang baik dan patut dicontoh membuat beliau digelari Syaikh Tarbiyah Indonesia. Keaktifannya dalam mensyi'arkan agama Islam dan semangatnya dalam memperjuangkan dakwah Islam perlu adanya pengenalan sosok KH. X beserta pola dakwah seperti apa yang beliau terapkan. Sebagai bentuk langkah perkembangan dakwah Islam. 
Berdasarkan latar belakang yang telah diuraikan, maka tujuan dalam penelitian ini diuraikan dalam pokok-pokok sebagai berikut:

a. Untuk mengetahui materi dakwah KH. Rahmat Abdullah.

b. Untuk mengetahui metode dakwah KH. Rahmat Abdullah.

c. Untuk mengetahui media dakwah KH. Rahmat Abdullah.

d. Untuk mengetahui gerakan dakwah Tarbiyah KH. Rahmat Abdullah.

\section{B. Metodologi Penelitian}

Penelitian ini menggunakan pendekatan kualitatif deskriptif yang ciri khasnya terletak pada pemikiran dakwah, yakni mendeskripsikan segala sesuatu yang berkaitan dengan aktivitas dakwah seorang tokoh dakwah yang berfokus pada materi, metode dan media serta gerakan dakwah Tarbiyah KH. Rahmat Abdullah. Penelitian ini bersifat penelitian kepustakaan, yaitu dengan mengumpulkan data-data pustaka baik dari buku-buku, majalah, dan media cetak lainnya yang berhubungan dengan tema penelitian.

Sumber data pada penelitian ini terbagi menjadi dua yaitu, sumber data primer berupa buku karya KH. X yang berjudul Untukmu Kader Dakwah dan Warisan Sang Murabbi, Pilarpilar Asasi dan sumber data sekunder yang berasal dari pihak lain. Berupa buku-buku, jurnal dan data-data yang diperoleh dari internet yang berkaitan dengan penelitian.

Metode yang digunakan untuk mengumpulkan data dalam penelitian ini adalah studi pustaka dengan menggunakan teknik pengumpulan data studi pustaka teknik simak. Langkahlangkahnya yaitu: Pertama, mengumpulkan buku-buku dan sumber-sumber terkait. Kedua, penulis melakukan pendalaman atau membaca buku-buku dan sumber-sumber yang telah didapatkan. Ketiga, mengatur dan mengolah data sehingga menghasilkan bahan untuk dijadikan deskripsi.

Data yang diperoleh selanjutnya dianalisis dengan menggunakan metode analisis isi. Dalam penelitian ini menggunakan teknik analisis model Miles and Huberman. Menurut Miles and Huberman dalam Sugiyono "mengemukakan bahwa aktivitas analisis data kualitatif dilakukan secara interaktif dan berlangsung secara terus menerus sampai tuntas, sehingga datanya sudah jenuh." Aktivitas analisis data yaitu data reduction (reduksi data), data display (penyajian data), dan conclusion drawing/ verification (simpulan/ verifikasi).

\section{Hasil Penelitian dan Pembahasan}

\section{Materi Dakwah KH. Rahmat Abdullah}

Bentuk-bentuk materi dakwah KH. X dituangkan dalam bentuk karya tulisan yang terdapat dalam buku Untukmu Kader Dakwah dan Warisan Sang Murabbi, Pilar-pilar Asasi dengan menganalisis isi buku terdapat beberapa pembahasan masalah aqidah, syari'ah dan akhlak.

a. Masalah Aqidah

Dalam buku Untukmu Kader Dakwah, pada bagian sepuluh prinsip-prinsip dakwah, KH. X menjelaskan bagaimana prinsip dakwah seorang kader dakwah atau aktivis dakwah yang baik. Masalah aqidah dalam sepuluh prinsip-prinsip dakwah yang pertama, prinsip Al-Ikhlas. Prinsip Al-Ikhlas berarti seluruh ucapan, perbuatan dan perjuangan seorang aktivis muslim selau ditujukan kepada Allah Swt serta memohon ridho hanya kepada-Nya. Semuanya dikerjakan dengan ikhlas karena Allah ta'ala, bukan karena makhluk atau selain kepada-Nya.

Kedua, prinsip At-Tsiqah atau kepercayaan. Dalam buku tersebut KH. X menjelaskan mengenai arti At-Tsiqah bahwa pusat pengendali tsiqah atau kepercayaan yaitu hanya tsiqah kepada Allah. Dengan menyerahkan diri dan amalnya dengan penuh tsiqah kepada-Nya, maka tidak aka nada sedikit keraguan di dalam dirinya, terhadap apa yang diamalkannya. Tsiqah kepada Allah harus menjadi landasan utama. Sebagaimana hal tersebut terjadi di dalam organisasi. Maka amanah seberat apapun serta perjuangan dan pengorbanan sebesar apapun dalam amal jama' $i$ tidak ada artinya. 
Dalam buku Warisan Sang Murabbi, Pilar-pilar Asasi, KH. X membahas salah satu masalah aqidah yaitu, berjudul Energi Cinta. Membahas tentang kuatnya cinta kepada Allah, yang dapat menyelamatkan hambanya dari kesesatan, kelemahan, kemiskinan dan tentunya keberkahan akan terasa kepadanya. Dengan melihat sepenggal kisah Islam terdahulu, saat lidah Said bin Jubair yang masih melafalkan Lailaaha illAllah yang tak sampai akhir kalimat, saat kepala dan jasadnya terpisah oleh pedang algojo. Kisah tersebut, membuktikan bahwa begitu besar cintanya kepada Allah hingga akhir hayatnya.

b. Masalah Syari'ah

Masalah syari'ah pada buku Untukmu Kader Dakwah dipembahasan sepuluh prinsipprinsip dakwah yaitu, pertama, prinsip Al-'Amal. Prinsip Al-'Amal yang dijelaskan KH. X bermaksud sifat seorang aktivis dakwah yang terjun ke masyarakat dan memberi petunjuk serta membimbing masyarakat dengan dakwah. Dalam diri dengan memperbaiki diri, dalam keluarga dapat membentuk dan membina keluarga muslim serta andil dalam perbaikan Negara.

Prinsip kedua yaitu, Al-Jihad. Al-Jihad dalam tulisan KH. X bermaksud sebagai bentuk pengorbanan dalam mengokohkan posisi dakwah oleh para aktivis dakwah. Jihad yang dimaksud di sini adalah jihad baik dengan tangan, tulisan, berkata benar maupun jihad dengan perang mengangkat senjata di jalan Allah.

Prinsip ketiga, At-Tadhhiyah yang berarti pengorbanan. Bentuk mengorbankan jiwa raga, harta dan waktu serta segala sesuatu dalam rangka mencapai tujuan. Bersangkut paut dengan jihad, karena tidak ada kata jihad di dunia ini tanpa adanya rasa pengorbanan. Keterkaitan antara jihad dan pengorbanan tetap selalu ada dalam menghidupkan dan mengembangkan dakwah.

Dan prinsip keempat, Al-Ukhuwwah yang berarti persaudaraan. Pada prinsip ini, KH. X menjelaskan bahwa persaudaraan merupakan kekuatan pertama bagi seorang aktivis dakwah. Mempererat tali persaudaraan merupakan bentuk mu'amalah antar umat muslim. Dengan ukhuwwah, para aktivis dakwah akan dapat menggabungkan hati dan ruh dengan tali aqidah, tali aqidah merupakan tali-tali yang paling kuat dan paling mahal.

Dalam bagian kedua pada buku Untukmu Kader Dakwah mengenai Dakwah Visioner. Masalah syari'ah pada bagian tersebut, mengenai Dinamika dalam Orisinalisasi dan Savety dalam Inovasi. KH. X menjelaskan bahwa seorang kader dakwah atau aktivis dakwah memiliki tugas untuk mensyi'arkan agama Islam dengan sebenar-benarnya. Sesuai dengan keaslian ajaran agama Islam dan tidak adanya menambah-nambahkan ajaran agama sebagai bentuk inovasi atau biasa yang disebut bid'ah.

Pada buku Warisan Sang Murabbi, Pilar-pilar Asasi dari tulisan KH. X yang berjudul Benalu. Beliau mengaitkan arti benalu dengan keberadaan 'benalu bangsa-bangsa', seperti orang-orang yang hanya merugikan orang lain dengan sifat keserakahan. 'Benalu di tubuh umat', seperti seorang pemerintah yang serakah. 'Benalu ibadah', seperti seseorang yang dalam dirinya terdapat hal yang menggoyahkan iman sehingga melupakan dan menghilangkan niat awal yang baik serta membuat diri seseorang keluar dari Islam. Karena terlena akan kemilauan dunia.

c. Masalah Akhlak

Masalah akhlak dalam buku Untukmu Kader Dakwah pada bagian sepuluh prinsipprinsip dakwah, pertama, terdapat pada prinsip Al-Fahmu atau paham. Dalam buku KH. X bermaksud bahwa dalam memahami Islam dengan fikrah Islamiyah (pandangan Islam) yang solid dan tangguh dalam kerangka dua puluh landasan yang ditulis oleh Hasan Al-Banna. Kedua, prinsip At-Tha'ah atau taat. Dengan maksud melaksanakan sekaligus menjalankan perintah-Nya tanpa menunda, baik dalam kelapangan maupun kesempitan, dalam suka maupun duka.

Prinsip ketiga, Ats-Tsabat yang berarti teguh. Maksud Ats-Tsabat yang tertulis oleh KH. $\mathrm{X}$ dalam bukunya adalah teguh dalam berdakwah. Bahwa sifat teguh, yang bisa mengalahkan semuanya adalah kepada para pejuang kebenaran yang tidak hanyut di air, tidak hangus di api, tidak melayang ditiup angin, tidak terlena dengan dunia. Karena hal yang mereka ingat adalah teguh dalam gerak dan gerak dalam teguh. 
Prinsip keempat, At-Tajarrud yang berarti totalitas. KH. X menuliskan maksud AtTajarrud yaitu, bahwa totalitas dilakukan dalam segala hal termasuk dalam menyampaikan ajaran Islam dengan sebenar-benarnya, dengan kebenaran yang bersumber dari Al-Qur'an dan Sunnah, totalitas dalam meneruskan perjuangan dakwah dengan risalah atau ajaran dari Rasulullah dalam berbagai aspek kehidupan.

Pada bagian dua buku tersebut membahas mengenai Dakwah Visioner. Pembahasan mengenai masalah akhlak, yaitu Perhatian Kepada Pembinaan Kader. KH. X menjelaskan bahwa pembinaan kader merupakan bentuk membangun karakter kader dakwah yang akan meneruskan perjuangan dakwah dengan siap menerobos segala rintangan dakwah. Pembinaan kader, hal pertama yang perlu diperhatikan. Karena risalah dakwah harus terus dilanjutkan dengan sebaik-baiknya, tanpa ada pengurangan maupun penambahan, yang membuat asholah dakwah hilang.

Pada buku Warisan Sang Murabbi, Pilar-pilar Asasi mengenai masalah akhlak, salah satunya berjudul Shidq atau jujur. KH. X menyatakan bahwa kejujuran merupakan kunci pembuka hati yang tidak ada tandingannya. Hidup dengan kejujuran memberi makna bagi kata iman dan taqwanya. Kejujuran menjadi indikator kekuatan jiwa dalam medan ujian hidup dan perjuangan.

\section{Metode Dakwah KH. Rahmat Abdullah}

Metode-metode yang penulis analisis dilihat dari cara penggunaan sarana dalam berdakwah. Berikut adalah metode-metode yang beliau gunakan mulai dari metode bil qalam, bil lisan, dan bil haal:

a. Metode Bil Qalam

Dakwah bil qalam KH. X dapat dilihat dari banyaknya tulisan-tulisan beliau yang dimuat dalam buku maupun rubrik majalah. Tulisannya dalam majalah Tarbawi di rubrik asasiyat, diterbitkan menjadi sebuah buku karya beliau yang berjudul Warisan Sang Murabbi, Pilar-pilar Asasi. Dan buku kedua berjudul Untukmu Kader Dakwah. Kedua buku tersebut berisi nasehat, pesan dan pengajaran dari kisah Islam terdahulu, yang dapat membantu para pembacanya untuk memahami isi dari tulisan-tulisannya serta menjadi pegangan yang tepat bagi para aktivis dakwah.

Dalam bidang ilmu sains, KH. X membahas studi kritis tokoh-tokoh yang bersangkutan dengan pemikirannya serta ditinjau dengan adanya ayat Al-Qur'an dan Hadits. Di antaranya: Benarkah Bumi Itu Datar? (Studi Kritis Konspirasi Bumi Datar Eric Dubay dan Boss Darling), Benarkah Matahari Mengelilingi Bumi? (Studi Kritis Teori Astronomi dalam Perspektif AlQur'an dan Hadits), dan Teori Absolutivitas Matahari Mengelilingi Bumi (Perjalanan Secara Ilmiah Teori Matahari Mengelilingi Bumi Ditinjau dari Ilmu Fisika dan Islam).

KH. X juga menulis buku mengenai tokoh dan kumpulan puisi-puisi religius. Pada buku pembahasan seorang tokoh, beliau menceritakan tokoh Syekh Siti Jenar dengan judul bukunya Syekh Siti Jenar: Pemutarbalikan Sejarah Perjalanan Hidup dan Ajarannya. Membahas perjalanan tokoh tersebut dengan ajarannya, pemikirannya dan menguak lebih dalam tokoh Syekh Siti Jenar. Buku beliau yang berjudul Sajadah Kata (Antologi Puisi Religius) membahas kumpulan puisi dengan untaian-untaian kata yang islami, sebuah bentuk perpaduan antara seni dan Islam. Sehingga menambah rasa mendalam saat membacanya.

b. Metode Bil Lisan

KH. X menyatakan di majalah Tarbawi, bahwa kegiatan dakwah sehari-hari beliau menggunakan metode bil lisan. Dengan mengisi tabligh, ceramah di masjid, kantor, kampus dan pengajian rutin di masjid Al-Qalam Islamic Center Iqro' serta mengajar di kelas SLTP I Terpadu Iqro'.

Metode bil lisan $\mathrm{KH}$. X yang lain di media massa adalah menjadi pembicara di rubrik radio. Beliau mengisi rubrik yang berjudul "Titik Pandang Rahmat Abdullah" dengan menyampaikan pemikiran-pemikirannya. Beliau juga menggagas dan mengisi rubrik Sakinah Mawaddah war Rahmah (SAMARA). Digagasnya rubrik SAMARA karena banyaknya orang yang berkonsultasi kepada beliau mengenai masalah keluarga di luar jadwal kegiatan dakwah beliau.

JRKPI is licensed under Creative Commons Attribution-

NonCommercial-ShareAlike 4.0 International License. Komunikasi Penyiaran Islam 
c. Metode Bil Haal

Metode bil haal membicarakan tentang metode dakwah dengan suatu perbuatan atau akhlak yang patut dijadikan contoh atau keteladanan. Keteladanan KH. X dapat dilihat dari perjalanan dakwah beliau. Seperti kreatifnya beliau dalam mengemas kegiatan dakwah dengan membangun pagelaran seni teater. Dari penjelasan M. Khoyyinudin di majalah Tarbawi, pagelaran pentas seni teater merupakan program dakwah beliau bersama para anggota Pemuda Raudhatul Falah (PARAF). Beliau menjadi sutradara sekaligus penulis naskah.

Pagelaran seni teater ini merupakan bentuk kegiatan dakwah dari penyatuan nilai seni dan Islam. Dalam seni teater, KH. X menyampaikan dakwahnya dengan menceritakan sejarahsejarah Islam. Hal ini menjadi salah satu bentuk kepedulian beliau terhadap lingkungannya serta kreatifnya beliau dalam berdakwah. Hal tersebut dapat menjadi contoh inovasi metode dakwah bagi para aktivis dakwah.

Dalam bidang jurnalistik KH. X mendirikan majalah Islam, yaitu Sabili. Bersama teman-teman Kelompok Telaah dan Amaliah Islam (KTAI) yang merupakan kelompok ilmiah gerakan Tarbiyah di ranah universitas. Beliau terjun ke bidang jurnalistik dengan mendirikan majalah Sabili sebagai salah satu media untuk berdakwah.

KH. X juga membangun yayasan yang bernama Islamic Center Iqra' bersama dengan para muridnya. Kepedulian beliau terhadap masyarakat Islam saat itu, kiprah dakwahnya dalam berbagai bidang dan keaktifannya dalam dunia pendidikan Islam, sehingga membuat beliau membangun yayasan yang bergerak di bidang pendidikan, sosial dan dakwah di wilayah Bekasi.

\section{Media Dakwah KH. Rahmat Abdullah}

Media-media dakwah yang digunakan KH. Rahmat Abdullah, dapat dilihat dari perjalanan dakwahnya. Dengan adanya keselarasan antara metode dan media dakwah yang digunakan. Berikut penulis uraikan media-media dakwah KH. Rahmat Abdullah.

a. Buku

Salah satu media tulisan KH. X adalah buku. Ada tujuh buku yang ditulis oleh beliau dari berbagai bidang ilmu, di antaranya: (1) Untukmu Kader Dakwah, (2) Warisan Sang Murabbi, Pilar-pilar Asasi, (3) Syekh Siti Jenar, (4) Sajadah Kata (Antologi Puisi Religius), (5) Benarkah Bumi Itu Datar? (Studi Kritis Konspirasi Bumi Datar Eric Dubay dan Boss Darling), (6) Benarkah Matahari Mengelilingi Bumi? (Studi Kritis Teori Astronomi dalam Perspektif AlQur'an dan Hadits), dan (7) Teori Absolutivitas Matahari Mengelilingi Bumi (Perjalanan Secara Ilmiah Teori Matahari Mengelilingi Bumi Ditinjau dari Ilmu Fisika dan Islam).

b. Ceramah

Salah satu media lisan yang KH. X lakukan adalah ceramah. Kegiatan ceramah beliau, dilakukan di kampus, kantor, masjid, Islamic Center Iqro' maupun di gerakan Tarbiyah. Ceramah merupakan media lisan, yang paling sederhana. Sebagaimana yang dikatakan Dr. Hamzah Ya'qub bahwa media lisan merupakan media yang murah dan paling sederhana yang menggunakan lidah dan suara.

c. Radio

Radio merupakan salah satu media lisan sekaligus media massa yang digunakan KH. X dalam berdakwah. Dakwahnya menggunakan radio adalah dengan mengisi sebuah rubrik pada program "Titik Pandang Rahmat Abdullah" setiap hari Sabtu jam 06.30 WIB dan menggagas rubrik Sakinah Mawaddah war Rahmah (SAMARA) serta menjadi pembicara setiap malam Rabu di Radio Dakta. Sebagaimana pernyataan tersebut, ditulis oleh M. Lili NA dari hasil wawancaranya kepada KH. X di majalah Tarbawi.

d. Keteladanan

Maksud dari keteladan di sini, merupakan akhlak atau perbuatan KH. X yang patut dicontoh. Keteladanan beliau, dapat dilihat dari pribadinya yang sabar dan bertanggung jawab, sebagaimana penjelasan Fahmi Irhamsyah pada buku Biografi Da'wah Syaikh Tarbiyah Indonesia (1972-2005), bahwa beliau bersama kakak dan adiknya, setelah ayahnya meninggal, saling bertanggung jawab mencari nafkah keluarga untuk memenuhi kebutuhan hidup dengan mengusahakan keberjalanan mesin cetak hand press milik ayahnya. 
Keteladanan selanjutnya, dapat dilihat dari semangatnya dalam berdakwah. Dengan penjelasan M. Khoyyinudin di majalah Tarbawi, bahwa semangat dakwah KH. X sudah ada sejak beliau remaja. Dengan menjadi seorang pendidik, yang merupakan langkah awal beliau dalam merintis dakwah. Kepedulian beliau terhadap Pendidikan Islam, dengan pengabdiannya menjadi seorang pendidik, beliau lakukan hingga bertahun-tahun.

Akhlak KH. X yang patut diteladani lagi adalah tegasnya beliau apabila Islam dilecehkan. Sikap beliau yang tegas pada hal-hal yang berkenaan dengan izzah Islam. menjadikan beliau sangat disegani. Sosok beliau yang tegas ini membuktikan bentuk kecintaannya kepada agama Allah Swt.

KH. X juga suka membaca buku. Membaca sudah menjadi kegiatan sehari-harinya. Dijelaskan oleh Istri beliau di majalah Tarbawi, bahwa beliau sosok yang berwawasan luas. Seseorang yang gemar membaca dan mau mempelajari banyak hal tentu ia adalah orang yang haus akan ilmu dan memiliki wawasan yang luas. Hal tersebut tentulah diperlukan oleh seorang aktivis dakwah, yang senantiasa tidak henti-hentinya untuk mempelajari ilmu.

Dengan penjelasan rekannya Hidayat Nur Wahid di majalah Sabili, bahwa rasa kepedulian KH. Rahmat Abdulah di gerakan dakwah Tarbiyah sangat terlihat. Dengan membina kader maupun di luar, kepada masyarakat. Hal ini dapat membuktikan bahwa dakwah tidak hanya sekadar figuritas, tetapi dia adalah yang terkait dengan nilai dan sistem. Sehingga sosok beliau selalu menghadirkan asholah atau keaslian dakwah dalam pemikirannya pada bingkai budaya dan empati terhadap masyarakat. Menjadikan bentuk kepedulian beliau sangat terasa.

\section{Gerakan Dakwah Tarbiyah KH. Rahmat Abdullah}

KH. X bergabung ke dalam gerakan Tarbiyah sejak tahun 80 -an. Bergabungnya beliau dengan gerakan Tarbiyah karena adanya keselarasan dakwah pribadinya dengan gerakan Tarbiyah, akhirnya beliau bertemu implementasiannya bersama teman-teman yang merintis pendidikan dan kaderisasi. Sehingga persentuhan pemikiran KH. X dengan gerakan Ikhwanul Muslimin yang akhirnya dapat menginspirasi gerakan dakwah Tarbiyah di Indonesia.

Bergabung dengan gerakan dakwah, menjadi bentuk kesempurnaan dakwah bagi $\mathrm{KH}$. $\mathrm{X}$ sebagai awal pergerakan dakwah Islam, sehingga bisa terus berjalan dan diteruskan oleh para kader-kader yang dibina di gerakan dakwah serta langkah awal membangun peradaban Islam.

Peran KH. X dalam gerakan Tarbiyah salah satunya di bidang kaderisasi. Menurut beliau gerakan Tarbiyah akan merubah cara pandang orang yang mengikutinya. Sebagaimana dalam pengalaman beliau saat membina mahasiswa di kampus, beberapa mahasiswa masih menganggap bahwa bidang ilmu yang diambilnya itu tidak baik, salah satunya mahasiswa yang mengambil jurusan Bahasa Inggris. Dia beranggapan bahwa Bahasa Inggris adalah bahasa kafir, sehingga ia malas untuk berkuliah.

Maka bagi mereka yang bergabung dengan gerakan Tarbiyah, akan mengambil pandangan dalam sisi yang baik, yaitu bahwa semua bidang ilmu akan memberikan kemanfaatan bagi diri sendiri dan orang lain. Karena ilmu itu tidak ada yang tidak baik, semua ilmu itu baik asalkan diri kita yang bisa menempatkan ilmu tersebut pada kebaikan. Inilah amanah para generasi penerus, sebagai agen perubahan yang dapat menjadikan setiap ilmu memiliki kebermanfaatannya masing-masing.

Gerakan Tarbiyah memiliki pola pendekatan dengan titik keilmuan yang disusun secara integral dan disajikan dengan tujuan menjadi lebih aplikatif. Hal yang menjadi contoh apliktifnya adalah ukhuwah. Di dalam gerakan Tarbiyah, ukhuwah di aplikasikan. Dengan adanya liqo' sebagai wadah pendekatan ruhani, akal dan jasadi, menjadikan keterikatan tali persaudaraan, karena kepahaman dalam Amal Jama'i terbina dalam liqo'. 
Di dalam gerakan Tarbiyah, KH. X memiliki peran yang cukup penting. Berikut penulis uraikan peran dan pengaruh beliau dalam gerakan Tarbiyah:

a. Menjadi Murabbi (Pengkader)

KH. X peran strategis dalam mencetak kader dakwah. Dengan perannya menjadi murabbi (pengkader) dan membina para kader-kader Tarbiyah, supaya kelak para kader dapat terus menjadi penggerak serta penerus perjuangan dakwah gerakan Tarbiyah. Perannya ini sudah beliau emban sejak bergabung dengan gerakan Tarbiyah. Pembinaan kader yang dilakukan pada gerakan Tarbiyah disebut sebagai liqo atau halaqah (melingkar).

b. Mendirikan Majalah Sabili

KH. X bersama kawan-kawan Kelompok Telaah dan Amaliah Islam (KTAI) yang anggotanya merupakan mahasiswa, mendirikan majalah Sabili sebagai salah satu media dakwah. Akan tetapi majalah Sabili ini tidak bertahan lama pada saat itu, karena tidak didirikan dengan cara resmi dan keberadaannya yang sembunyi-sembunyi. Didirikannya majalah Sabili, sebagai media untuk mengkritik penguasa serta memberikan informasi pada seluruh kader Tarbiyah yang berkaitan dengan Islam.

c. Mendirikan Partai

KH. X memiliki peran yang cukup penting dalam pembentukan partai, dengan menjadi penggagas dalam penamaan partai, membuat visi dan misi serta menjadi pembaca do'a saat acara deklarasi partai. Peran penting KH. X yang lainnya adalah dengan amanahnya menjadi Ketua Majelis Syuro dan Ketua Majelis Pertimbangan Partai, Partai Keadilan Sejahtera (PKS). Bagi beliau, amanahnya saat itu hanya pindah ruang dan tanggung jawab dakwah satu dengan variasinya saja. Pada pemilu tahun 2004. Beliau diamahkan menjadi anggota DPR RI. Amanah beliau tersebut menjadi akhir perjalanan dakwah beliau, hingga beliau kembali kepada-Nya.

d. Mendapati Gelar Syaikh Tarbiyah

Banyaknya peran dan pengaruh beliau dalam gerakan Tarbiyah serta sosoknya yang banyak memberikan inspirasi bagi perkembangan gerakan dakwah, maka beliau mendapati gelar dengan sebutan Syaikh Tarbiyah Indonesia. Para kader dakwah maupun para aktivis dakwah yang berada di dalam gerakan Tarbiyah merasa pantas bagi beliau bila diberikan gelar tersebut. Peran dan pengaruhnya masih terasa hingga saat ini bagi para kader maupun aktivis dakwah gerakan Tarbiyah.

Sebagaimana pembahasan di atas, bahwa pola dakwah yang mencakup materi, metode dan media dakwah KH. X yang menjadi bentuk dakwah pribadinya serta penyatuan pemikiranpemikirannya. Menjadi hal yang berpengaruh pada pergerakan dakwah Tarbiyah di Indonesia.

\section{Kesimpulan}

Berdasarkan pembahasan dalam penelitian ini, penulis menyimpulkan beberapa hasil penelitian sebagai berikut:

1. Materi dakwah KH. X terdapat pada tulisan-tulisannya, yang berada di dalam bukunya yang berjudul "Untukmu Kader Dakwah" dan "Warisan Sang Murabbi, Pilar-pilar Asasi". Pada buku tersebut materi-materi dakwah beliau mencakupi masalah aqidah, syari'ah dan akhlak.

2. Metode dakwah KH. X terdapat empat metode, yaitu metode bil qalam (metode dengan tulisan), metode bil lisan (metode dengan suara) dan metode bil haal (metode dengan akhlak atau perbuatan).

3. Media dakwah KH. X berkaitan dengan metode dakwah yang digunakannya. Ada empat media yang beliau gunakan, yaitu buku (media tulisan), Ceramah (media lisan), radio (media elektronik), keteladanan (media akhlak atau perbuatan).

4. Gerakan dakwah Tarbiyah menurut KH. X adalah merubah cara pandang orang yang mengikutinya. Gerakan Tarbiyah memiliki mazhab yang sama dengan keyakinan bersama umat Islam. Hal yang membedakan adalah pola pendekatan dengan titik keilmuan yang disusun secara integral dan disajikan dengan tujuan menjadi lebih aplikatif. Banyaknya peran dan pengaruh KH. X dalam gerakan Tarbiyah, sehingga beliau diberi gelar Syaikh Tarbiyah Indonesia. 


\section{Acknowledge}

Penelitian ini tidak akan terwujud tanpa adanya bantuan dari berbagai pihak. Dengan ini, penulis mengucapkan terima kasih kepada para dosen pembimbing dalam memberikan segala arahan pada penelitian ini, kepada pihak perpustakaan yang senantiasa memberikan akses dalam peminjaman buku untuk keberlangsungan penelitian, kepada kedua orang tua yang senantiasa memberi semangat dan dukungan serta kepada teman-teman seperjuangan yang selalu memberikan motivasi dan saran selama proses penelitian.

\section{Daftar Pustaka}

[1] Moh. Ali Aziz. 2004, ILMU DAKWAH, Bandung: Prenada Media.

[2] Izomiddin, 2018, Pemikiran dan Filsafat Hukum Islam, Jakarta: Prenada Media.

[3] M Lili NA, "Denyut Nadinya adalah Denyut Dakwahnya" dalam Ahmad Zairofi AM (Ed), Bercermin di Telaga Cinta Sang Guru. 2005, Jakarta: Tarbawi.

[4] Ilyas Ismail dan Prio Hotman. 2011, Filsafat Dakwah: Rekayasa Membangun Agama dan Peradaban Islam, Jakarta: Prenada Media Group.

[5] Fahmi Irhamsyah. 2019, Biografi Da'wah Syaikh Tarbiyah Indonesia (1972-2005), Bandung: Mujahid Press

[6] Sugiyono. 2005, Metode Penelitian Pendidikan Pendekatan Kuantitatif, Kualitatif, dan $R \& D$, Bandung: Alfabeta

[7] Hidayat Nur Wahid, "Ia Penjaga Asholah yang Tidak Membuat Partai Jadi Kerdil" dalam Ahmad Zairofi AM (Ed), Bercermin di Telaga Cinta Sang Guru. 2005, Jakarta: Tarbawi.

[8] M. Khoyyinudin, "KH. Rahmat Abdullah, Dari Kuningan Sampai Bekasi" dalam Ahmad Zairofi AM (Ed), Bercermin di Telaga Cinta Sang Guru. 2005, Jakarta: Tarbawi.

[9] Rahmat Abdullah. 2019, Warisan Sang Murabbi, Pilar-pilar Asasi, Tangerang: Ihsan Media. [10] —. 2020, Untukmu Kader Dakwah. Tangerang: Ihsan Media.

[11] Mohammad Hasan. 2013, Metodologi Pengembangan Ilmu Dakwah, Surabaya: Pena Salsabila.

[12] Sumarni, "Semoga Anak-anak Bisa Menggantikan Abinya" dalam Ahmad Zairofi AM (Ed), Bercermin di Telaga Cinta Sang Guru. 2005, Jakarta: Tarbawi.

[13] Nia Kurniati Syam, "Dakwah dalam Perspektif Modernisme Antisipasi Menuju Postmodernisme" dalam Mediator, No. 1, Vol. 6, Tahun 2005. 